\title{
Knowledge, Attitude and Practice of Caregivers on Medication Management at Residential Aged Care Facilities in Malaysia
}

\author{
MARIANI AN, MARHANIS-SALIHAH O, ADLIAH MA, MOHD MB \\ Centre of Quality Management of Medicine, Faculty of Pharmacy, Universiti Kebangsaan \\ Malaysia, Jalan Raja Muda Abdul Aziz, 50300 Kuala Lumpur, Malaysia
}

\begin{abstract}
ABSTRAK
Peningkatan jumlah warga tua dikaitkan dengan penambahan masalah dalam penjagaan kesihatan. Dengan kerumitan penyakit yang berkaitan dengan usia, sistem pengurusan ubat yang baik adalah penting untuk mencegah kesilapan ubat. Kajian ini bertujuan untuk membangunkan soal selidik untuk menilai pengetahuan, sikap dan amalan (KAP) penjaga terhadap pengurusan ubat di rumah jagaan kejururawatan (RACFs). Satu kajian keratan rentas telah dijalankan dan melibatkan penjaga dari 90 RACF di seluruh Malaysia. Soal selidik yang dibangunkan berdasarkan tinjauan literatur dan pendapat pakar ini mengandungi 41 item yang dibahagikan kepada tiga domain. Dalam kajian ini, kadar respons adalah $71 \%$ dengan 128 soal selidik yang dikembalikan. Skor median yang diperolehi untuk pengetahuan, sikap dan amalan masing-masing adalah 77.27, 70.83 dan 68.66. Majoriti penjaga (71.9\%) disifatkan mengetahui asas pengurusan ubat, bagaimanapun, hampir separuh daripada mereka (48.4\%) tidak pernah menerima sebarang latihan mengenainya. Lebih separuh daripada penjaga mempunyai tahap pengetahuan yang baik $(69.5 \%, n=89)$, separuh lagi $(57.8 \%, n=74)$ mempunyai sikap yang baik dan kurang daripada separuh mempunyai amalan yang baik (46.9\%) terhadap pengurusan ubat. Tahap pendidikan, kelayakan khusus dan pengalaman latihan pengurusan ubat adalah faktor yang dikaitkan dengan hasil skor yang baik $(p<0.05)$. Oleh itu, diharapkan lebih banyak sokongan dan latihan dapat diberikan kepada para penjaga di RACF mengenai pengurusan ubat.
\end{abstract}

Kata kunci: pengurusan terapi perubatan, rumah jagaan kejururawatan, umur tua

\section{ABSTRACT}

An escalating proportion of the aged group is associated with a growth in the

Address for correspondence and reprint requests: Marhanis-Salihah Omar. Centre of Quality Management of Medicine, Faculty of Pharmacy, Universiti Kebangsaan Malaysia, Jalan Raja Muda Abdul Aziz 50300 Kuala Lumpur, Malaysia. Tel: +603-9289 8055 Email: marhanis@ukm.edu.my 
prevalence of ill health. With the complexity of age-related diseases, a good medication management system is important to prevent medication errors. This study was aimed to develop a questionnaire to assess the knowledge, attitude and practice (KAP) of caregivers on medication management at residential aged care facilities (RACFs). A cross-sectional study was performed involving caregivers from 90 RACFs throughout Malaysia. The validated self-administered questionnaire was developed based on the extensive literature review and expert's opinions containing 41-items divided into three domains. In this study, the response rate was $71 \%$ with 128 questionnaires returned. Median scores obtained for knowledge, attitude and practice were 77.27, 70.83 and 68.66, respectively. Majority of the caregivers $(71.9 \%)$ deemed to know what medication management was. However, nearly half of them (48.4\%) did not experience any training. More than half of the caregivers possessed good level of knowledge $(69.5 \%, n=89)$, around half $(57.8 \%$, $n=74)$ had a good attitude and less than half had a good practice $(46.9 \%, n=60)$ of medication management. Level of education, special qualification and experience of medication management training were the factors that correlated with good score outcome $(p<0.05)$. Therefore, it is assumed that more support and training can be provided to the caregivers in RACF on medication management.

Keywords: aged, patient-centered care, medication therapy management

\section{INTRODUCTION}

Medication management is a complex process, comprising few phases such as prescribing, transcribing, dispensing, administering, monitoring and storing (Dilles et al. 2011). Patient safety is crucial in the healthcare system and any errors in medication management process may contribute to the unsafe practice. The use of medication is complicated in elderly population due to their multiple co-morbidities or the atypical presentation of symptoms that often results in polypharmacy.

Meanwhile, the elderly population in Malaysia is increasing and those 65 years and above are expected to increase to 4.4 million in the next few years. There is an increase demand in residential aged care facilities (RACFs) which provide a long-term skilled care for dependent elderly (Ahmad-Nizaruddin et al. 2017). The formal caregivers play an important role in managing aged resident's daily activities, however, studies on caregiver's medication management is limited. While some of the RACFs are staffed by trained nurses and supported by a visiting doctor or therapist, majority of the facilities however have the caregivers as the only person-incharge of the resident's medication (Wei \& Omar 2017). This impedes the guidance for policy decisions in medication management area. Thus, assessing the knowledge, attitude and practice of the caregivers on medication management is important 
to enable proper interventions or recommendations to that specific setting. Therefore, this study was aimed to develop a questionnaire to assess the knowledge, attitude and practice (KAP) of caregivers on medication management at RACFs.

\section{MATERIALS AND METHODS}

Based on the concept of 5 Rights of medication, a structured questionnaire was developed and constructed. This concept emphasises medication for the right patient, the right drug, the right dose, the right route, and the right time (Grissinger 2010). The literature search was carried out using relevant journal databases such as Science Direct, Scopus, PubMed, Cochrane database, Mendeley and Medline. Several keywords such as "knowledge, attitude and practice", "caretakers", "caregivers", "residential aged care facilities", "medication management" and "medication administration" were used throughout the literature search.

$$
\text { After the questionnaire }
$$
conceptualisation, relevant statements or questions were developed and arranged according to the specific domains. The first draft of the questionnaire was constructed in Malay language. Appropriate scales of measurements and questionnaire layout were decided. The content validity of the questionnaire was confirmed based on the expert opinion of two pharmacists and one medical practitioner. Following that, the questionnaire was given to the translator language expert to conduct a back translation for Malay language and English.

The final questionnaire comprised of five sections, namely demographic (Section 1 and Section 2) with total of 9 items, Section 3: knowledge (22 items), Section 4: attitude (6 items) and Section 5: practice (13 items). The internal consistency reliability measured by Cronbach's coefficient alpha for knowledge attitude practice was $0.631,0.666$ and 0.575 , respectively. Questionnaires were then delivered by post to the two caregivers per center of the 90 RACF listed in the Ministry of Women, Family and Community Development website. Consideration was made to include all possible RACFs from each state in Malaysia. Telephonic follow-up was made to ensure that caregivers received the questionnaire via post. An explanation for the purpose of the research was made available in the questionnaire along with the consent form. The study protocol was reviewed and approved by the University Human Research and Ethnics Committee (UKM PPI/111/8/ JEP-2016-523).

Descriptive statistics were utilised to calculate the continuous variables as mean and standard deviation (SD), and categorical variables as percentages. There were 22 validated questions in the knowledge domain. Scoring for knowledge included true/false/ not sure responses. Correct responses were awarded 1 and incorrect or not sure response was awarded 0 . The attitude domain of six validated questions employed a Likert scale of five points which is "Strongly Agree, Agree, Neutral, Disagree and Strongly Disagree". The points given varied 
Table 1: Demographic characteristics

\begin{tabular}{|c|c|c|c|c|}
\hline Characteristics & & & Frequency, n (\%) & Mean \pm SD \\
\hline \multirow{9}{*}{$\begin{array}{l}\text { Residential aged } \\
\text { care facilities }\end{array}$} & \multirow[t]{3}{*}{ Number of residents } & Less than 10 & $13(10.2 \%)$ & \\
\hline & & Between 10-29 & $53(41.4 \%)$ & \\
\hline & & More than 30 & $62(48.8 \%)$ & \\
\hline & \multirow{3}{*}{$\begin{array}{l}\text { Organisational } \\
\text { governance or } \\
\text { ownership }\end{array}$} & Government & $7(5.5 \%)$ & \\
\hline & & Private & $72(56.3 \%)$ & \\
\hline & & Non-Government & $49(38.3 \%)$ & \\
\hline & \multirow[t]{3}{*}{ Location of RACF } & Urban & $104(81.3 \%)$ & \\
\hline & & Sub-urban & $15(11.7 \%)$ & \\
\hline & & Rural & $9(7.0 \%)$ & \\
\hline \multirow[t]{23}{*}{ Caregivers } & \multirow[t]{3}{*}{ Age (years) } & $18-30$ & $43(33.6 \%)$ & $41.30 \pm 14.3$ \\
\hline & & $31-49$ & $51(39.8 \%)$ & \\
\hline & & 50 or above & $34(26.6 \%)$ & \\
\hline & \multirow[t]{2}{*}{ Gender } & Male & $40(31.3 \%)$ & \\
\hline & & Female & $88(68.8 \%)$ & \\
\hline & \multirow[t]{4}{*}{ Ethnicity } & Malay & $47(36.7 \%)$ & \\
\hline & & Chinese & $42(32.8 \%)$ & \\
\hline & & Indian & $23(18.0 \%)$ & \\
\hline & & Others & $16(12.5 \%)$ & \\
\hline & \multirow[t]{2}{*}{ Nationality } & Malaysian & $113(88.3 \%)$ & \\
\hline & & Non-Malaysian & $15(11.7 \%)$ & \\
\hline & \multirow{5}{*}{$\begin{array}{l}\text { Highest educational } \\
\text { level }\end{array}$} & No formal education & $6(4.7 \%)$ & \\
\hline & & Primary education & $11(8.6 \%)$ & \\
\hline & & Secondary education & $56(43.8 \%)$ & \\
\hline & & Diploma holders & $39(30.5 \%)$ & \\
\hline & & Degree holders or above & $16(12.5 \%)$ & \\
\hline & \multirow{3}{*}{$\begin{array}{l}\text { Length of Services in } \\
\text { RACF (years) }\end{array}$} & Less than 10 & $88(68.8 \%)$ & $9.26 \pm 7.86$ \\
\hline & & $11-29$ & $33(25.8 \%)$ & \\
\hline & & 30 years or above & $7 \quad(5.5 \%)$ & \\
\hline & \multirow{2}{*}{$\begin{array}{l}\text { Special qualification } \\
\text { related to RACFs }\end{array}$} & Yes & $64(50.0 \%)$ & \\
\hline & & No & $64(50.0 \%)$ & \\
\hline & \multirow{2}{*}{$\begin{array}{l}\text { Ever received any } \\
\text { training on medication } \\
\text { management }\end{array}$} & Yes & $66(51.6 \%)$ & \\
\hline & & No & $62(48.4 \%)$ & \\
\hline
\end{tabular}

from 0 to 24. Practice domain was based on 13 questions to measure the level of practice on medication management. Regarding the practice section, 'Always' showed a maximum frequency of event and was assigned the highest score which ranged from 0 to 65 . All 13 practice questions were calculated by adding up the scores of and taking into account reverse scoring 
in the case of negatively quoted questions.

In this study, the Chi-square test was used to determine the association between the categorical variables. For the cut-off points, the scores in knowledge, attitude and practice domains were categorised as poor (50\% and below), moderate (51 to $69 \%$ ) and good (70\% and above). Any possible correlation between knowledge, attitude and practice was determined by Spearman's correlation test. The Statistical Package for the Social Sciences (SPSS) software for the Windows version 23.0 was used to analyse the collected data accordingly.

\section{RESULTS AND DISCUSSION}

Of all 180 caregivers targeted in this study, the questionnaires were filled and returned by 128 (71\%) of caregivers. The mean age of respondents was 41 years and their length of service was approximately 9 years. More than half of the respondents $(57.1 \%$, $\mathrm{n}=73$ ) had attained secondary level education and $48.4 \%$ of them $(n=62)$ had not experienced any training on medication management (Table 1).

For the knowledge section (Table $2)$ majority of the respondents $(71.9 \%, \mathrm{n}=92)$ knew what medication management was. However, only half knew there are ' 5 rights' related to medication administration. More than half of the respondents $(55.5 \%$, $n=71$ ) were not sure whether different dosage forms had different storage conditions. Majority of the respondents opted to double the dose when the residents missed any medication dose $(77.3 \%, n=98)$. About $69.5 \%$ of the respondents were not sure of the difference between adverse drug effect and drug side-effect. Close to half of the respondents did not agree that medication management was the main problem in nursing homes $(46.9 \%, n=60)$ but many admitted that caregivers should receive training in managing medication (84.4\%, $\mathrm{n}=108$ ).

The median scores obtained for knowledge, attitude and practice were 77.27, 70.83 and 68.66, respectively. A scoring system was developed and scores of caregivers for each domain were analysed and further categorised as good, moderate and poor as listed in Table 3. More than half of the respondents possessed good level of knowledge $(69.5 \%, \mathrm{n}=89)$, more than half had a good attitude $(57.8 \%, n=74)$ and less than half of the respondents had a good practice $(46.9 \%, n=60)$ of medication management. Factors such as level of education, special qualification and experience of medication management training correlated with good score outcomes $(p<0.05)$. There was a weak positive correlation between the level of knowledge and caretaker's attitude $\left(p=0.001^{*}, r=0.294\right)$ as well as between practice and caretaker's attitude ( $p$ $=0.01 *, r=0.146)$. Meanwhile, there was a significant association between knowledge of the caregiver with their education level, special qualification of caregivers and medication management training.

Health problems are a major hindrance of healthy lifestyle for the elderly and a suitable living condition is warranted to help them improve 
Table 2: Frequency of various responses to questions

\begin{tabular}{|c|c|c|c|c|c|}
\hline Knowledge & $\begin{array}{c}\text { Item } \\
\text { no }\end{array}$ & Description of Question & $\begin{array}{l}\text { Yes } \\
\text { n (\%) }\end{array}$ & $\begin{array}{l}\text { No } \\
\text { n (\%) }\end{array}$ & $\begin{array}{c}\text { Not sure } \\
\text { n (\%) }\end{array}$ \\
\hline & 1 & I know what medication management is & $92(71.9)$ & 17(13.3) & $19(14.8)$ \\
\hline & 2 & $\begin{array}{l}\text { I know there are five rights ( } 5 \mathrm{R}) \text { related to } \\
\text { medication administration }\end{array}$ & 75 (58.6) & $31(24.2)$ & $22(17.2)$ \\
\hline & 3 & $\begin{array}{l}\text { I know the right timing for administrating all } \\
\text { medication is after food }\end{array}$ & $45(35.2)$ & 0 & $84(64.8)$ \\
\hline & 4 & $\begin{array}{l}\text { I know different medication has different route } \\
\text { of administration }\end{array}$ & $114(89.1)$ & $7(5.5)$ & $7(5.5)$ \\
\hline & 5 & $\begin{array}{l}\text { I know if residents misses a medication dose, } \\
\text { the next dose should be doubled }\end{array}$ & $99(77.3)$ & $29(22.7)$ & 0 \\
\hline & 6 & $\begin{array}{l}\text { I know label on medication should have the } \\
\text { name of the medication }\end{array}$ & $114(89.1)$ & $5(3.9)$ & $8(6.3)$ \\
\hline & 7 & $\begin{array}{l}\text { I know label on medication should have expiry } \\
\text { date }\end{array}$ & 107 (83.6) & $6(4.7)$ & $15(11.7)$ \\
\hline & 8 & $\begin{array}{l}\text { I know label on medication should have } \\
\text { resident's name }\end{array}$ & $119(93)$ & $2(1.6)$ & $7(5.5)$ \\
\hline & 9 & $\begin{array}{l}\text { I know label on medication should have route } \\
\text { of administration }\end{array}$ & $105(82)$ & $7(5.5)$ & $16(12.5)$ \\
\hline & 10 & $\begin{array}{l}\text { I know different dosage form has different } \\
\text { storage condition }\end{array}$ & $56(43.8)$ & $1(00.8)$ & $71(55.5)$ \\
\hline & 11 & $\begin{array}{l}\text { I know all medications must be kept in the } \\
\text { refrigerator }\end{array}$ & $68(53.1)$ & 0 & $60(46.9)$ \\
\hline & 12 & $\begin{array}{l}\text { I know all medications must be kept in a cool } \\
\text { and dry place }\end{array}$ & $115(89.8)$ & $6(4.7)$ & $7(5.5)$ \\
\hline & 13 & $\begin{array}{l}\text { I know all medication must be keep away from } \\
\text { direct sunlight }\end{array}$ & 107 (83.6) & $14(10.9)$ & $7(5.5)$ \\
\hline & 14 & $\begin{array}{l}\text { I know the difference between side effect and } \\
\text { adverse drug effect }\end{array}$ & 39 (30.5) & 0 & $89(69.5)$ \\
\hline & 15 & $\begin{array}{l}\text { I know all medications have adverse drug } \\
\text { reaction }\end{array}$ & $78(60.9)$ & $32(25)$ & $18(14.1)$ \\
\hline & 16 & $\begin{array}{l}\text { I know adverse drug reaction can be prevented } \\
\text { by dose adjustment }\end{array}$ & $88(68.8)$ & $19(14.8)$ & $21(16.4)$ \\
\hline & 17 & $\begin{array}{l}\text { I know follow up is needed after initiating the } \\
\text { medication }\end{array}$ & 94 (73.4) & $13(10.2)$ & 20 (15.6) \\
\hline & 18 & $\begin{array}{l}\text { I know resident's allergy to some medication } \\
\text { must be informed to doctor }\end{array}$ & $108(84.4)$ & $12(9.4)$ & $8(6.3)$ \\
\hline & 19 & I know what medication error is & $70(54.7)$ & $17(13.3)$ & $40(31.3)$ \\
\hline & 20 & $\begin{array}{l}\text { I know adverse drug event of the medication } \\
\text { must be documented }\end{array}$ & $96(75)$ & $13(10.2)$ & $19(14.8)$ \\
\hline & 21 & I know medication error must be documented & $89(69.5)$ & $16(12.5)$ & $23(18)$ \\
\hline & 22 & $\begin{array}{l}\text { I know resident's allergy on medication must be } \\
\text { documented }\end{array}$ & $100(78.1)$ & $9(7)$ & 19 (14.8) \\
\hline
\end{tabular}




\begin{tabular}{|c|c|c|c|c|c|c|}
\hline Attitude & & $\begin{array}{l}\text { Strongly } \\
\text { Agree }\end{array}$ & Agree & Neutral & Disagree & $\begin{array}{l}\text { Strongly } \\
\text { Disagree }\end{array}$ \\
\hline 1 & $\begin{array}{l}5 \mathrm{R} \text { concept can lead to good } \\
\text { medication management }\end{array}$ & $59(46.1)$ & $23(18)$ & $35(27.3)$ & $6(4.7)$ & $5(3.9)$ \\
\hline 2 & $\begin{array}{l}\text { Medication management is the main } \\
\text { problem in nursing homes }\end{array}$ & $11(8.6)$ & 25 (19.5) & $32(25)$ & $36(28.1)$ & 24 (18.8) \\
\hline 3 & $\begin{array}{l}\text { Older patients will have more } \\
\text { problems in taking the medication }\end{array}$ & 33 (25.8) & $31(24.2)$ & 28 (21.9) & $18(14.1)$ & $18(14.1)$ \\
\hline 4 & $\begin{array}{l}\text { Right storage of medication can give } \\
\text { a good effect to the patient }\end{array}$ & 59 (46.1) & $44(34.4)$ & $18(14.1)$ & $4(3.1)$ & $2(1.6)$ \\
\hline 5 & $\begin{array}{l}\text { Do you agree that caregivers } \\
\text { should be given training session on } \\
\text { medication management }\end{array}$ & 69 (53.9) & 39 (30.5) & $12(9.4)$ & $5(3.9)$ & $2(1.6)$ \\
\hline 6 & $\begin{array}{l}\text { Do you agree having a record book } \\
\text { for patient is important }\end{array}$ & $70(54.7)$ & $35(27.3)$ & 15 (11.7) & $4(3.1)$ & $2(1.6)$ \\
\hline Practice & & Always & $\begin{array}{l}\text { Very } \\
\text { often }\end{array}$ & $\begin{array}{l}\text { Some } \\
\text { times }\end{array}$ & Rarely & Never \\
\hline 1 & $\begin{array}{l}\text { How often do you check the identity } \\
\text { of the resident before administer the } \\
\text { medication to the resident }\end{array}$ & 79 (61.7) & $36(28.1)$ & $10(7.8)$ & $1(0.8)$ & $2(1.6)$ \\
\hline 2 & $\begin{array}{l}\text { How often do you check the dose of } \\
\text { the medication before administer to } \\
\text { resident }\end{array}$ & $80(62.5)$ & $29(22.7)$ & 15 (11.7) & $3(2.3)$ & $1(0.8)$ \\
\hline 3 & $\begin{array}{l}\text { How often do you check the timing } \\
\text { of the medication before you } \\
\text { administer to the patient }\end{array}$ & $64(50.0)$ & $27(21.1)$ & 25 (19.5) & $5(3.9)$ & $7(5.5)$ \\
\hline 4 & $\begin{array}{l}\text { How often do you document } \\
\text { all medications that you had } \\
\text { administered to the resident in the } \\
\text { record book }\end{array}$ & $41(32.0)$ & 3225.0 & $34(26.6)$ & $9(7.0)$ & $12(9.4)$ \\
\hline 5 & $\begin{array}{l}\text { How often do you crush the tablet } \\
\text { if the patient unable to consume the } \\
\text { medication }\end{array}$ & $21(16.4)$ & $17(13.3)$ & 25 (19.5) & 15 (11.7) & $50(39.1)$ \\
\hline 6 & $\begin{array}{l}\text { How often do you mistakenly give } \\
\text { the wrong dose to the patient }\end{array}$ & $6(4.7)$ & $0(0)$ & $15(11.7)$ & 43 (33.6) & $64(50)$ \\
\hline 7 & $\begin{array}{l}\text { How often do you get complaint } \\
\text { from the patient after they took the } \\
\text { medication }\end{array}$ & 38 (29.7) & $13(10.2)$ & $21(16.4)$ & 17 (13.3) & 39 (30.5) \\
\hline 8 & $\begin{array}{l}\text { How often do you notice any wrong } \\
\text { labelling on the medication }\end{array}$ & 34 (26.6) & 11 (8.6) & $27(21.1)$ & 19 (14.8) & 37 (28.9) \\
\hline 9 & $\begin{array}{l}\text { How often do you keep all the } \\
\text { medications under sunlight }\end{array}$ & 28 (21.9) & 15 (11.7) & $14(10.9)$ & $7(5.5)$ & $64(50.0)$ \\
\hline 10 & $\begin{array}{l}\text { How often do you inform the doctor } \\
\text { if the medication is not labelled }\end{array}$ & $29(22.7)$ & $33(25.8)$ & $30(23.4)$ & $9(7.0)$ & $27(21.1)$ \\
\hline 11 & $\begin{array}{l}\text { How often do you ensure that the } \\
\text { medication is stored at the right place }\end{array}$ & 39 (30.5) & $45(35.2)$ & $30(23.4)$ & $5(3.9)$ & $9(7.0)$ \\
\hline 12 & $\begin{array}{l}\text { How often do you follow up on the } \\
\text { patient after initiating the medication }\end{array}$ & 25 (19.5) & 49 (38.3) & $32(25.0)$ & $13(10.2)$ & $9(7.0)$ \\
\hline 13 & $\begin{array}{l}\text { How often do you observe adverse } \\
\text { drug reaction experienced by patient }\end{array}$ & $0(0)$ & $27(21.1)$ & $29(22.7)$ & $22(17.2)$ & $15(11.7)$ \\
\hline
\end{tabular}


Table 3: Scoring of domain characteristics and Knowledge, Attitude and Practice

\begin{tabular}{lcccc}
\hline \multirow{2}{*}{$\begin{array}{l}\text { Domain } \\
\text { characteristic }\end{array}$} & Median Score & \multicolumn{3}{c}{ Number of respondent (n, \%) } \\
\cline { 3 - 4 } & 77.27 & $89(69.5 \%)$ & $31(24.2 \%)$ & $8(6.3 \%)$ \\
\hline Knowledge & 70.83 & $74(57.8 \%)$ & $30(23.4 \%)$ & $24(18.8 \%)$ \\
Attitude & 68.66 & $60(46.9 \%)$ & $54(42.2 \%)$ & $14(10.9 \%)$ \\
Practice & & Good & Moderate & \\
\hline
\end{tabular}

*Good Score (70-100\%); Moderate Score (51-69\%); Poor Score (<50\%)

their quality of life (Selvaratnam et al. 2012). There are few settings of RACFs in Malaysia with different practices. Certain RACFs are run as a business of profit by companies while others are run by non-profit organisations and are sponsored by charitable groups or by government agencies. RACFs with experienced and qualified nursing staff tend to result in less medication error (Tangiisuran et al. 2018). Qualifications in providing care to this special community population is important. A lack of in-service training and inadequate knowledge of staff in nursing homes may lead to the medication error (Pape et al. 2005). It is a concern that the personnel handling medication management are largely secondary school leavers, do not hold any special qualification and have not had any previous training in medication management. To enhance patient safety, staff should be closely supervised and provided with continuous education (Wilson et al. 2010). Ongoing education in medication management is essential to ensure primary care systems are age-friendly, with appropriately trained healthcare professionals.

Polypharmacy is often associated with side-effects as well as drug-drug interactions among elderly (Razali et al. 2012). Furthermore, poor physical function was identified as one of the risk factors for frailty in elderly (Badrasawi et al. 2017). With the medication management knowledge limitation pose by the caretaker as observed in our current study, it may lead to medication errors. Notably, RACF residents are at the highest risk of medication errors, including administration and dispensing error as they move between primary and secondary care (Amanda et al. 2016). Medication errors are indeed largely attributed to the poor practices and inadequate knowledge, followed with problems of communication between the caretaker and the elderly (Stefanacci \& Riddle 2016). This is important in elderly as drug adverse effects such as hypotension, osteoporosis and hypoglycemia can contribute to falling (Loke et al. 2018).

Our present study also demonstrated a need for intervention as it was shown that there was a relationship between special qualifications, medication management training and education level towards positive attitude and practice behavior. Age-associated physical decrement along with chronic diseases affected the drug-use behaviors of the elderly (Oguzoncul et al. 2018). The caregivers also need to 
cope up with the difficulties in managing residents with special medication needs (Zamzam et al. 2011). In our opinion, lack of training also brought to the compromising the quality and safety of resident care in RACF. High work burden, shortage of staff and limited expenses allocated in running a RACF may limit the training. However, involvement of other healthcare professional such as community pharmacist may be beneficial to aid in training and monitoring for medication management.

Nevertheless, in this study, as the questionnaire was self-administered, the caregivers may overestimate or underestimate their practice and attitude. Another limitation was the cross-sectional nature of the study that was unable to demonstrate any changes of knowledge, attitude and practice of medication management over time. Several aspects of medication management were also not covered in this present study, e.g. ample, the provision of medicine information and shared decision making in creating management plan. Hence, the study can be extended by developing more questions to measure wider area on medication management.

\section{CONCLUSION}

The questionnaire is a valid and practical tool to assess the knowledge, attitude and practice of caregivers on medication management at RACFs. Although caregivers have good knowledge, but much can be improved in the area of attitude and practice, to the establishment of good governance and policies to support the medication management system practiced at the respective RACFs. More support and training may be provided to caregivers on medication management and its system as certain terms such as medication error and adverse drug reaction are unfamiliar to them.

\section{ACKNOWLEDGEMENT}

The authors thank Universiti Kebangsaan Malaysia for the grant funding (grant number FRGS/2/2014/ SKKK02/UKM/03/1).

\section{REFERENCES}

Ahmad-Nizaruddin, M., Omar, M.S., Mhd-Ali, A., Makmor-Bakry, M. 2017. A qualitative study exploring issues related to medication management in residential aged care facilities. Patient Prefer Adherence 11: 1869-77.

Amanda, H.L., Gallagher, P.F., O-Mahony, D. 2016. Methods to reduce prescribing errors in elderly patients with multimorbidity. Clin Interv Aging 11857-68.

Badrasawi, M., Shahar, S., Sing, D.A. 2017. Risk factors of frailty among multi-ethnic Malaysian older adults. Int / Geronto/ 11(3): 154-60.

Dilles, T., Monique, M., Elseviers, M.S., Bart, V.R., Lucas, M., Robert, R. 2011. Barriers for nurses to safe medication management in nursing homes, Health policy and systems. I Nurs Scholarsh 43(2): 171-80.

Grissinger, M. 2010. The five rights a destination without a map. PT 35(10): 542.

Loke, M.Y., Gan, L.Y., Islahudin, F. 2018. Awareness of medication related falls and preferred interventions among the elderly. Pak J Pharm Sci 31(2): 359-64.

Oguzoncul, A.F., Ercan, E., Ceebi, E. 2018. Identification of the drug-use behaviors of the elderly living in nursing homes. Clin Interv Aging 13: 1225-30.

Pape, T.M., Guerra, D.M., Muzquiz, M., Bryant, J.B., Ingram, M., Schranner, B. 2005. Innovative approaches to reducing nurses' distractions during medication administration. J Contin Educ Nurs 36: 108-16.

Razali, R., Baharudin, A., Nik Jaafar, N.R. 2012. Factors associated with mild cognitive 
impairment among elderly patients attending medical clinics in Universiti Kebangsaan Malaysia Medical Centre. Sains Malays 41(5): 641-7.

Selvaratnam, D.P., Abu-Bakar, N., Idris, N.A. 2012. The health determinants of elderly Malaysian population. Prosiding PERKEM VII. 2:1195-1199.

Stefanacci, R., Riddle, A. 2016. Preventing medication error. Geriatric Nursing 37(4): 307-13.

Tangiisuran, B., Tye, S.C., Leow, M.Y., Awang, R. 2018. Comparison of nurses and general caregivers' knowledge, attitude, and practice on medication administration process and their distress level in long-term care facilities across Penang, Kuala Lumpur, and Selangor of Malaysia. Aging Clin Exp Res 30(2): 183-91.

Wei, T.M., Omar, M.S. 2017. Self-management approaches among hypertensive residents in nursing homes in Malaysia. Malays Fam Physician 12(3): 8-17.

Wilson, N.M., March L.M., Sambrook, P.N., Hilmer, S.N. 2010. Medication safety in residential aged- care facilities: a perspective. Ther $A d v$ Drug Saf 1(1): 11-20.

Zamzam, R., Midin, M., Hooi, L.S., Yi, E.J., Ahmad, S.N.A., Azman, S.F.A., Borhanuddin, M.S., Radzi, R.S.M. 2011. Schizophrenia in Malaysian families: A study on factors associated with quality of life of primary family caregivers. Int J Ment Health Syst 5: 16.

Received: 28 Mar 2020

Accepted: 06 Aug 2020 